\title{
Development and Application of SATEEC L Module for Slope Length Adjustment Based on Topography Change
}

\author{
Hyunwoo Kang, Ki-sung Kim, Youn Shik Park, Namwon Kim ${ }^{1)}$ \\ Yong Sik $\mathrm{Ok}^{2)}$, Jonggun Kim, Yun $\mathrm{Ho} \mathrm{Choi}^{3)}$, and Kyoung Jae $\mathrm{Lim}^{\dagger}$ \\ Department of Regional Infrastructures Engineering, Kangwon National University \\ ${ }^{1)}$ Water Resources Research Division, Korea Institute of Construction Technology \\ ${ }^{2)}$ Department of Biological Environment, Kangwon National University \\ ${ }^{3)}$ Water Pollution Cap System Research Division, National Institute of Environmental Research \\ (Received June 1, 2009, Accepted June 15, 2009)
}

\begin{abstract}
Severe sediment-laden problem has been the hot issue in Korea. It was assumed that agricultural activities and landslides were the primary causes of these problems in watersheds. The USLE-based systems have been widely used in soil erosion studies. However the GIS-based USLE modeling system has limitation in USLE $L$ factors. In this study, the SATEEC $L$ module was developed to reflect the slope length segmentations in the fields. The SATEEC $L$ module was applied to the study watershed to analyze the effects of using the SATEEC $L$ module on estimated sediment. As shown in the comparisons between SATEEC estimated sediment with SWAT values, the SATEEC GA-SDR module derives the SDR with reasonably acceptable accuracies. However, it is worthy to note that the soil erosion using the SATEEC $L$ module for the study watershed was lower than that without using the SATEEC L module by $25 \%$, although the SATEEC estimated sediment values with and without using $L$ module match the SWAT sediment values with similar accuracies. This is because the SATEEC GA-SDR module estimates lower SDR in case of greater soil erosion estimation without the $L$ module and greater SDR in case of lower soil erosion estimation with the $L$ module. This indicates that the SATEEC input parameters, especially $L$ factor, need to be prepared with care for accurate estimation of SDR at a watershed scale and for accurate evaluation of BMPs in the watershed.
\end{abstract}

Key Words: USLE, SATEEC, Soil Erosion, Field Slope Length, LS

\section{Introduction}

In the last decade, severe sediment-laden problem has been the hot issue in Korea. It was assumed that agricultural activities and landslides were the primary causes of these problems in watersheds ${ }^{1)}$. There are many soil erosion models available such as Universal Soil Loss Equation (USLE) ${ }^{2}$, Water Erosion Prediction Project $(\mathrm{WEPP})^{3)}$, Soil and Water Assessment Tool (SWAT) ${ }^{4)}$, European Soil Erosion

\section{"연락저자:}

Tel: 033-250-6468 Fax: 033-251-1518

E-mail: kjlim@kangwon.ac.kr
Model (EUROSEM) ${ }^{5}$, and others. These models have been developed for their application purposes, thus the input requirements vary significantly. Among these models, the USLE has been widely used worldwide over the years because of its ease-of-use, and extensively available input data. There are many USLE-based soil erosion models, also the USLE has been integrated with GIS by many researchers. ${ }^{6778)}$

The Sediment Assessment Tool for Effective Erosion Control (SATEEC) system ${ }^{9}$ was developed in the ArcView GIS 3.x platform with numerous Avenue programming for soil erosion and sediment yield estimation using the USLE input dataset. The SATEEC system requires Digital Elevation Model 
(DEM) and only USLE input data sets such as the Rainfall-Runoff erosivity factor (R), Soil Erodibility $(\mathrm{K})$, Crop and Management factor $(\mathrm{C})$, and Practice factor $(\mathrm{P})$ to estimate soil erosion. Also the sediment yield can be estimated for any location within a watershed with a Sediment Delivery Ratio (SDR) using watershed area or watershed slope in the SATEEC system ver. $1.5^{9)}$ and using various factors in SATEEC system ver $2.0^{10)}$. It was developed with the philosophy of "very limited dataset for reasonable soil erosion estimation" and "ease-to-use". The SATEEC system ver. 2.0 considers temporal changes in rainfall, crop growth, and surface covers for soil erosion estimation. It has been well known that Non-Point Source Pollution (NPSP) discharge is related to rainfall patterns. Also in agriculturally-dominant watersheds, the NPSP is highly related with crop type and crop growth, because crop canopy covers the soil surface and reduces the rainfall impact before the rainfall reaches soil surface. The SATEEC system ver. 2.0 simulates soil erosion and sediment yield reflecting temporal changes of watershed. However, it cannot reflect the segmentations of slope length in real fields. In most GIS modeling including SATEEC system ver. 2.0, the USLE L factor is calculated by flow direction and flow accumulation without consideration of slope length segmentation by road or agricultural canals (Fig. 1).

The objectives of this study were 1) to develop L module in SATEEC system for monthly and yearly soil erosion and sediment yield estimation reflecting segmentations of slope length; and 2) to apply the SATEEC L module to demonstrate how it can be used in practical soil erosion studies.

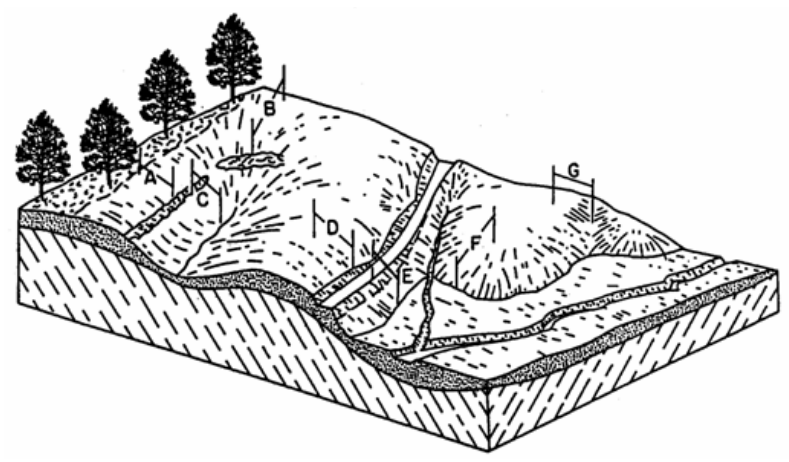

Fig. 1. Field Slope Length at Watershed ${ }^{11)}$. (A-G : segmentations of slope length in real fields)

\section{METHODOLOGY}

In this study, the Gangwon-do Yanggu-gun Haean-myeon watershed (altitude : $38^{\circ} 17^{\prime} 14^{\prime \prime}$ longitude : $\left.128^{\circ} 8^{\prime} 18^{\prime \prime}\right)$ was selected (Fig. 2). The watershed is $1,361 \mathrm{~km}^{2}$ in size. Primary land-uses in this watershed are forest $79.8 \%$, agricultural areas $16.0 \%$, residential areas $1.4 \%$, water $2.4 \%$, and pasture $0.4 \%$, respectively (http://www.wamis.go.kr)

\section{SATEEC System Overview}

Fig. 3 shows how the SATEEC system ver. 2.0 simulates soil erosion and sediment yield using the USLE input dataset. SATEEC 2.0 simulates monthly and yearly soil erosion and sediment yield with USLE input data and readily available daily rainfall data by Time-Variant $\mathrm{R}$ module and daily $\mathrm{C}$ DB by Time-Variant $\mathrm{C}$ module. A daily rainfall data measured

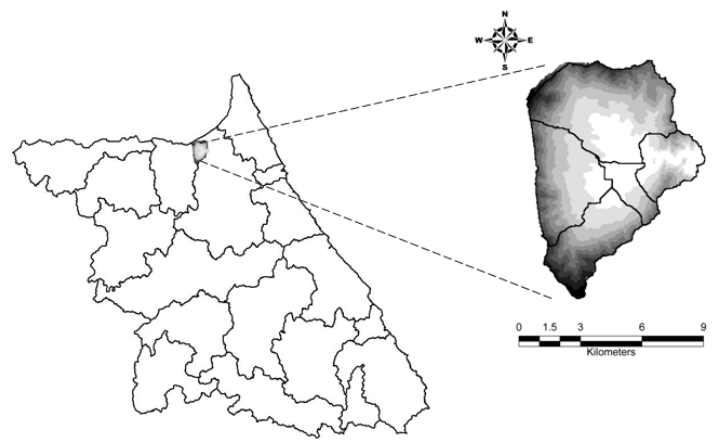

Fig. 2. Location of Haean-myeon watershed in Yanggu-gun Gangwon-do.

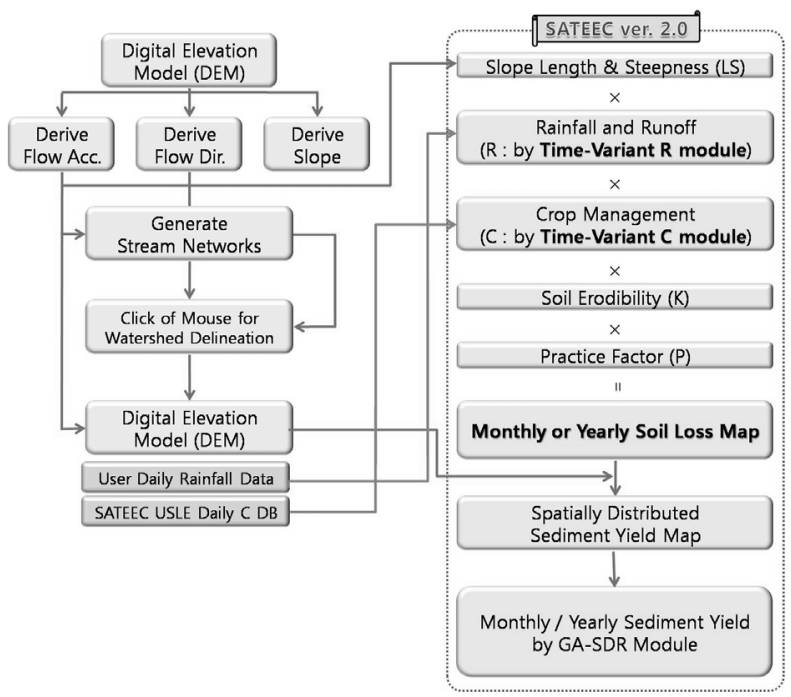

Fig. 3. Overview of the SATEEC System ${ }^{10)}$. 
in study area and daily C DB in SATEEC 2.0 for the Time-Variant $C \cdot R$ modules were used to reflect temporal changes such as rainfall, crop growth, canopy height and crop cover in study area. The Sediment Delivery Ratio (SDR) has been used with USLE-based GIS model to explain sediment transport and deposition to the watershed outlet. There are many methods to estimate SDR, such as watershed area-based SDR, slope-based SDR and various factors-based SDR. In th SATEEC system ver. 2.0, the Genetic-Algorithm SDR (GA-SDR) was used to reflect sediment deposition and transport to the outlet with various watershed factors.

\section{DEVELOPMENT OF SATEEC L MODULE}

The LS factor used in soil erosion simulation using the SATEEC 2.0 is estimated using DEM, but the slope lengths are segmented by roads or other man-made structures, such as agricultural canals in the fields. Flow length is calculated based on flow direction map. therefore it is considered to be continuous if no break is found in either flow direction or flow accumulation. Thus, USLE L factor not only in SATEEC system but also models based on GIS system is generally overestimated, because the segmentations of slope length due to many factors in the fields are not considered. Therefore, the $\mathrm{L}$ module for SATEEC system was developed to consider the segmentation of slope length by roads or other human-made structures in the fields.

Segmentations of slope length were considered with the boundaries of agricultural areas and roads built data based on Gangwon developement Research

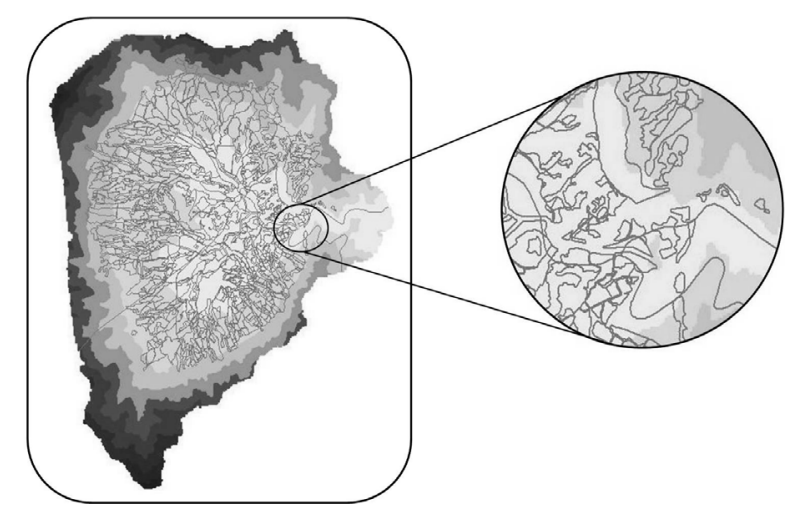

Fig. 4. Slope Length Segmentation due to Agricultural Field Boundaries.
Institude's data in Haean-myeon watershed (Fig. 4.).

\section{APPLICATION OF GA-SDR in SATEEC 2.0 SYSTEM}

Soil erosion models, such as USLE ${ }^{2)}$ and MUSLE ${ }^{12)}$ estimate soil erosion rate at field-scale. Soil erosion values estimated by USLE or USLE-based model are often higher than measured data at watershed outlet, because these USLE-based models assume eroded soils are transported to the watershed outlet. To estimate transported sediment at watershed outlet, the Sediment Delivery Ratio (SDR) is used ${ }^{13)}$. It is defined as the fraction of net soil erosion that is transported from a watershed. It can be expressed as

$$
\mathrm{SDR}=\mathrm{Y} / \mathrm{E}
$$

where $\mathrm{Y}$ is average annual sediment yield per unit area and $\mathrm{E}$ is average annual erosion over that same area. It estimates sediment yield that is actually transported from the watershed to watershed outlet. And it usually has a value between 0 and 1 , because the sediment can be deposited when flow velocity is decreased. Once in a while, the SDR values are larger than 1 caused by gully erosion near outlet or breaking of bank. There many are methods to estimate SDR, such as SDR based on watershed area $^{14(15) 16)}$, SDR based on slope ${ }^{17)}$ :

$$
\begin{aligned}
& S D R=0.472^{*} A R E A^{-0.125} \quad(2)^{14),} \\
& S D R=0.5656^{*} A R E A^{-0.11} \quad(3)^{15)}, \\
& S D R=0.3750^{*} A R E A^{-0.2382} \quad(4)^{16)}, \\
& S D R=0.627^{*} S L O P E^{0.403} \quad(5)^{17)},
\end{aligned}
$$

where AREA is watershed area $\left(\mathrm{km}^{2}\right)$ and SLOPE is slope $(\%)$ of watershed.

However, these SDR methods have limitation in simulating sediment deposition and transport occurring in the watershed. To overcome these limitation in explaining sediment delivery mechanism, the Genetic Algorithm-Sediment Delivery Ratio (GA-SDR) module in the SATEEC 2.0 was used. It estimates SDR based on Equation 6 to consider the various watershed factors such as area, slope, and CN. It estimates a coefficient and 3 of exponents using the genetic algorithm incorporated in the SATEEC 2.0 system.. 


$$
\mathrm{SDR}=\mathrm{A} \times \mathrm{AREA}^{\mathrm{B}} \times \mathrm{SLOPE}^{\mathrm{C}} \times \mathrm{CN}^{\mathrm{D}}
$$

Where, A - D are coefficient and exponents that are determined by genetic algorithm ${ }^{18}$, AREA is area of watershed $\left(\mathrm{km}^{2}\right)$, SLOPE is a ratio of height and horizontal distance $(\mathrm{m} / \mathrm{km}), \mathrm{CN}$ is a curve number.

\section{ESTIMATION OF SEDIMENT YIELD WITH SATEEC SYSTEM WITH L MODULE}

Daily precipitation data from Jan. $1^{\text {st }} 1993$ to Jul. $31^{\text {st }} 2007$ at Inje-gun Gangwon-do was used, The daily precipitation values were used to calculate yearly/monthly USLE $\mathrm{R}$ factor by Time-Variant $\mathrm{R}$ module in the SATEEC 2.0 system (Fig. 5) ${ }^{10}$.

The USLE K factor reflects a soil erosion potential by properties of soil such as size distribution, soil structure, and organic content. The USLE $\mathrm{K}$ factor values were estimated by Modified Universal Soil Loss Equation (MUSLE) ${ }^{12)}$ equation (Equation 7).

$$
\begin{aligned}
K= & \left(0.2+0.3 \exp \left(-0.0256 S A N\left(1-\left(\frac{S I L}{100}\right)\right) \times\right.\right. \\
& \left(1.0-\left(\frac{0.25 C L A}{C L A+\exp (3.72-2.95 C)}\right) \times\right. \\
& \left(1.0-\left(0.7 \frac{S N 1}{S N 1+\exp (-5.51+22.9 S N 1)}\right)\right.
\end{aligned}
$$

Where SAN, SIL and CLA are the ratio (\%) of sand, silt and clay, SN1 is 1-SAN/100. The USLE P factor is the factor for supporting conservation practices. The standard condition for USLE $P$ is direct up-and-down the slope cultivation. USLE $P$ factor values were estimated by slope with below table

\begin{tabular}{|c|c|c|c|c|}
\hline \multicolumn{2}{|c|}{ re_dkr_precip.dbf } & - & $\square$ & 36 \\
\hline Dof? & $F_{i p q}$ & & & \\
\hline 19930101 & 0.00 & & & ث \\
\hline 19930102 & 0.00 & & & 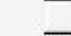 \\
\hline 19930103 & 0.00 & & & \\
\hline 19930104 & 0.00 & & & \\
\hline 19930105 & 0.00 & & & \\
\hline 19930106 & 0.00 & & & \\
\hline 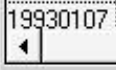 & 0.00 & & & $\div$ \\
\hline
\end{tabular}
$(\text { Table } 1)^{2}$. Fig. 6 shows the USLE K and USLE P factor maps for the study watershed.

In the SATEEC system, the method recommended

Fig. 5. Daily Precipitation for Hae-an Area.
Table 1. USLE P Factors for Various Land Uses and Slopes

\begin{tabular}{c|c|c}
\hline Land use & \multicolumn{2}{|c}{ P factor } \\
\hline \hline Paddy land & \multicolumn{2}{|c}{0.2} \\
\hline \multirow{5}{*}{ Upland } & Slope & P factor \\
\cline { 2 - 3 } & $0 \% \sim 2 \%$ & 0.60 \\
\cline { 2 - 3 } & $2 \% \sim 7 \%$ & 0.50 \\
\cline { 2 - 3 } & $7 \% \sim 12 \%$ & 0.60 \\
\cline { 2 - 3 } & $12 \% \sim 18 \%$ & 0.80 \\
\cline { 2 - 3 } & $18 \% \sim 24 \%$ & 0.90 \\
\cline { 2 - 3 } & $24 \% \sim 30 \%$ & 0.95 \\
\cline { 2 - 3 } & $>30 \%$ & 1.00 \\
\hline
\end{tabular}
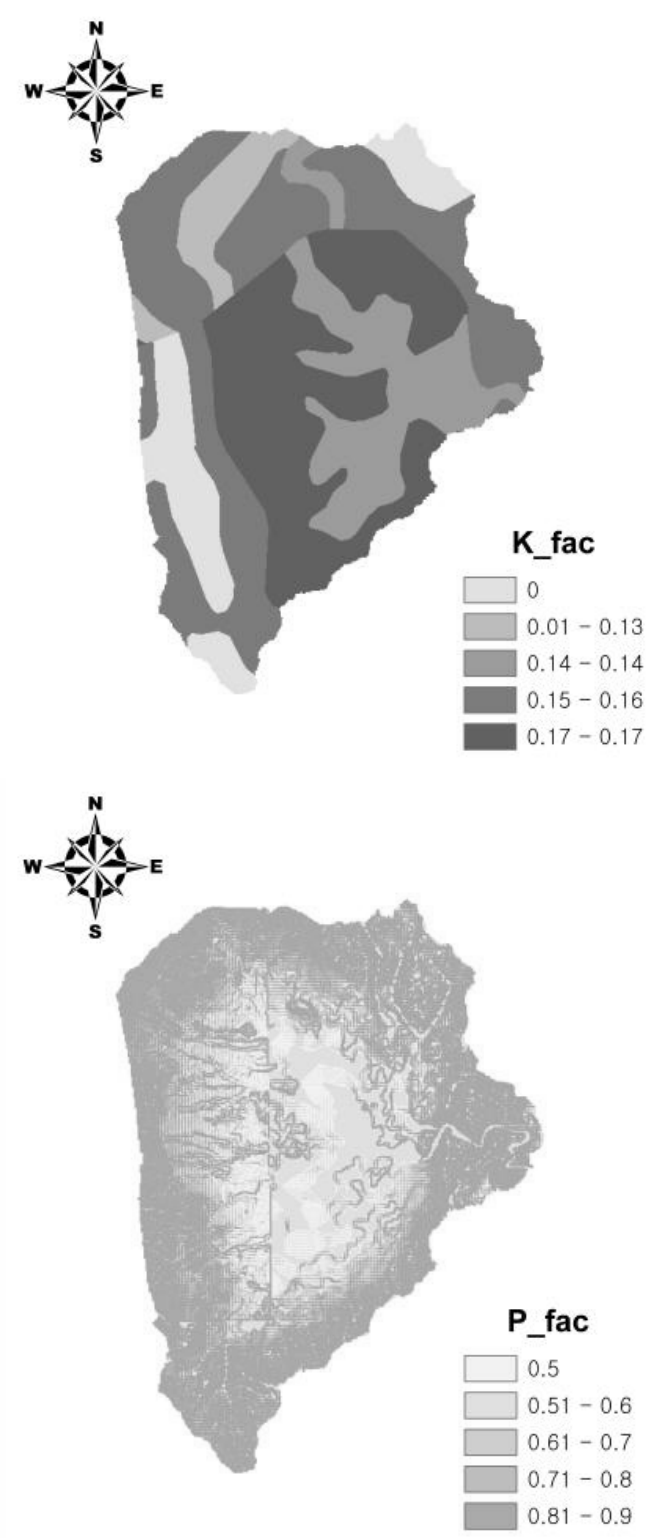

Fig. 6. USLE $K$ and $P$ factor in SATEEC system. 
by Moore and Burch ${ }^{1920)}$ are used to calculate the LS factor from the 'flow accumulation map' calculated using the DEM in SATEEC system ${ }^{9}$. According to the RUSLE User"s Guide ${ }^{11)}$, the length of hill slopes in the USLE experimental plots ranged from $10.7 \mathrm{~m}$ (35

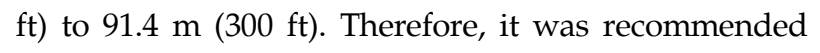
that the use of slope lengths less than $122 \mathrm{~m}(400 \mathrm{ft})$ are desired because overland flow becomes concentrated into the rills in less than $122 \mathrm{~m}(400 \mathrm{ft})$ under natural condition ${ }^{11}$. In the SATEEC the USLE LS factor values are computed (Fig. 7) with the recommended equation by Moore and Burch $^{19)}$ 20) (Equation 8) and an upper bound of slope length is provided by users, such as $122 \mathrm{~m}$ (400 ft).

$$
L S=\left(\frac{A}{22.13}\right)^{0.6}\left(\frac{\sin \theta}{0.0896}\right)^{1.3}
$$

In this study, the SATEEC L module was applied using agricultural field boundary map to reflect topography changes in the fields, resulting in reduced LS values, which were not possible with other GIS-based USLE, such as SATEEC system ver $2.0^{10)}$.

In agriculturally-dominant watersheds, the soil erosion is relevant with surface condition such as crop type and crop growth, because crop canopy covers the soil surface and reduces the rainfall impact to some degree before it reaches the soil surface. To reflect these changes of surface condition, the

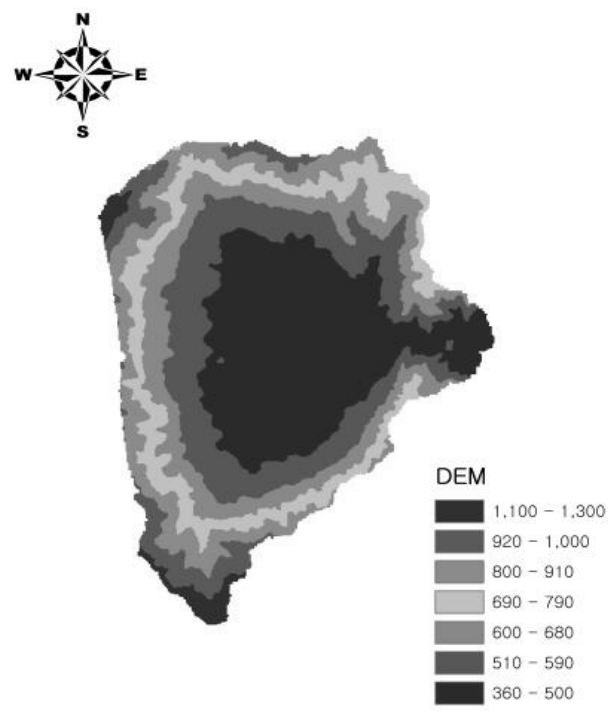

(a) DEM (Digital Elevation Model)

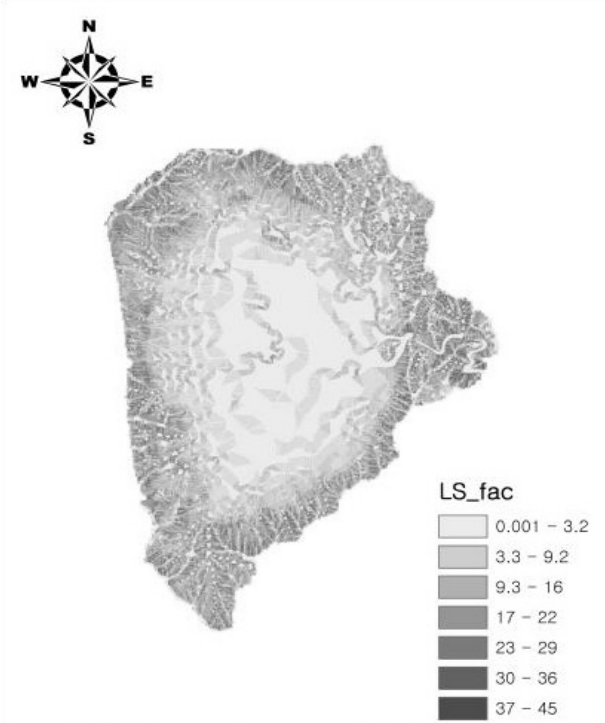

(b) LS (Slope length and steepness)

Fig. 7. Calculation of LS using DEM in SATEEC system.

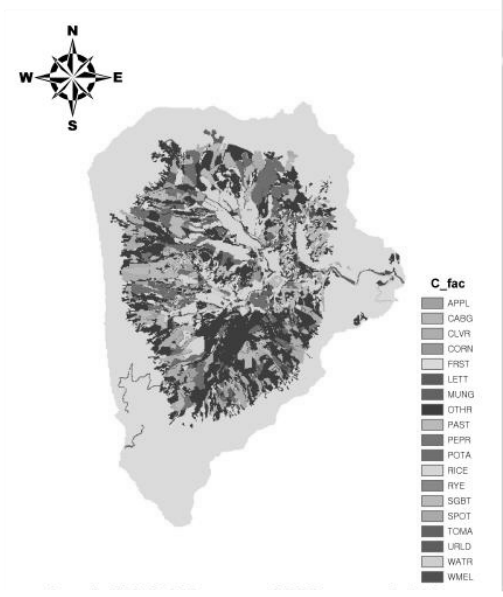

\begin{tabular}{|c|c|c|c|c|c|c|}
\hline \multicolumn{5}{|c|}{ sateec_varying_c_data.dbf } & - & \multirow{2}{*}{$\square$ x } \\
\hline drag & $\mathrm{Cnt}$ & Fols & Cokgy & Leff & Bino: & \\
\hline 1 & 0.217347 & 0.656859 & 0.376322 & 0.160055 & 0.430355 & $\overline{0.2583 t}$ A \\
\hline 2 & 0.217347 & 0.656860 & 0.376323 & 0.160056 & 0.430356 & 0.25835 \\
\hline 3 & 0.217347 & 0.656861 & 0.376325 & 0.160057 & 0.430357 & $0.2583 \varepsilon$ \\
\hline 4 & 0.217348 & 0.656862 & 0.376326 & 0.160057 & 0.430358 & $0.2583 i$ \\
\hline 5 & 0.217348 & 0.656862 & 0.376327 & 0.160058 & 0.430359 & $0.2583 \varepsilon$ \\
\hline 6 & 0.217348 & 0.656863 & 0.376327 & 0.160059 & 0.430360 & $0.2583 \varepsilon$ \\
\hline 7 & 0.217348 & 0.656864 & 0.376328 & 0.160059 & 0.430361 & 0.25836 \\
\hline 8 & 0.217348 & 0.656864 & 0.376329 & 0.160060 & 0.430362 & $0.2584 \mathrm{C}$ \\
\hline 9 & 0.217348 & 0.656865 & 0.376330 & 0.160061 & 0.430363 & 0.25841 \\
\hline 10 & 0.217348 & 0.656871 & 0.376331 & 0.160061 & 0.430364 & $0.2584 c^{\prime}$ \\
\hline 11 & 0.217348 & 0.656880 & 0.376332 & 0.160062 & 0.430364 & 0.25844 \\
\hline 12 & 0.217348 & 0.656884 & 0.376333 & 0.160062 & 0.430365 & 0.25845 \\
\hline 13 & 0.217348 & 0.656885 & 0.376333 & 0.160062 & 0.430366 & 0.25845 \\
\hline 14 & 0.217349 & 0.656887 & 0.376334 & 0.160063 & 0.430367 & $0.2584 E$ \\
\hline 15 & 0.217349 & 0.656888 & 0.376335 & 0.160063 & 0.430368 & $0.2584 i$ \\
\hline 16 & 0.217349 & 0.656889 & 0.376336 & 0.160063 & 0.430369 & $0.2584 i$ \\
\hline 17 & 0.217349 & 0.656890 & 0.376337 & 0.160064 & 0.430370 & $0.2584 \varepsilon$ \\
\hline 18 & 0.217349 & 0.656891 & 0.376338 & 0.160064 & 0.430371 & $0.2584 \varepsilon$ \\
\hline 1 & & & & & & 7 \\
\hline
\end{tabular}

Fig. 8. USLE C factor in SATEEC system. 
Time-Variant C module (Fig. 8) ${ }^{10)}$ in SATEEC system ver. 2.0 was used in this study.

\section{COMPARISON OF SATEEC WITH L MODULE and SWAT}

In this study, the SATEEC with L module estimated sediment values were compared with SWAT simulated data. Although the SATEEC with L module estimated values should be compared with measured data for validation of the model, the SATEEC estimated values were compared with SWAT estimated data in this study, which is calibrated and validated with measured data for a bigger watershed containing Haean-myeon watershed.

\section{RESULTS and DISCUSSION}

\section{DEVELOPMENT OF SATEEC L MODULE}

In this study, the SATEEC L module was developed and integrated with SATEEC 2.0 system to consider slope-length segmentation by human-made structures. Two options "Preprocess DEM excluding ROADs" and "Derive LS Factor Map w/ ROADs excluded DEM" were added under the SATEEC 2.0 menu (Fig. 9) for easy application of the SATEEC 2.0 system with newly-developed SATEEC L module.

As shown in Fig. 10, USLE L factor values without $\mathrm{L}$ module (Fig. 10 (a)) were higher than those with $\mathrm{L}$ module (Fig. 10(b)). USLE L factor values without L module were estimated without consideration of slope segmentation, thus the flow length was assumed to be continuos from the upper areas although it is not in the fields.

\section{SOIL EROSION ESTIMATION USING SATEEC L MODULE}

In this study, the SATEEC L module was applied to the Haean-myeon watershed (Fig. 11). Fig 11 (a) shows the $\mathrm{L}$ factor estimated without the $\mathrm{L}$ module and Fig. 11 (b) shows the L factor estimated with L module. As shown in the Fig. 11 (a), the L factor values were assumed to the same value at the flat areas, the maximum value (120 meter, upper limit value provided by the SATEEC users) although the agricultural field boundaries block the flow from upper areas. However, the flow length was splitted
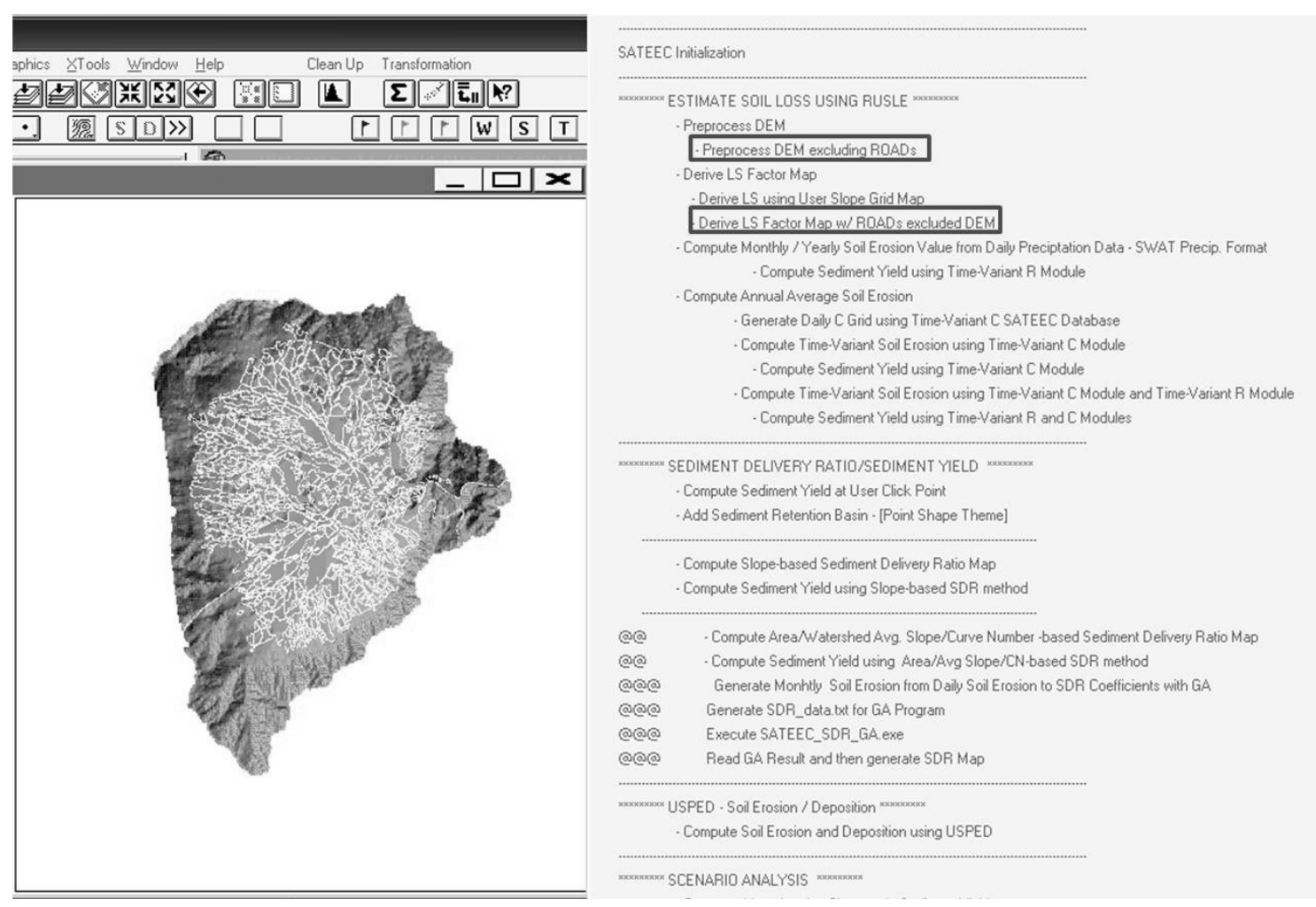

Fig. 9. Interface of $\mathrm{L}$ module in SATEEC system ver. 2.0. 
<smiles></smiles>

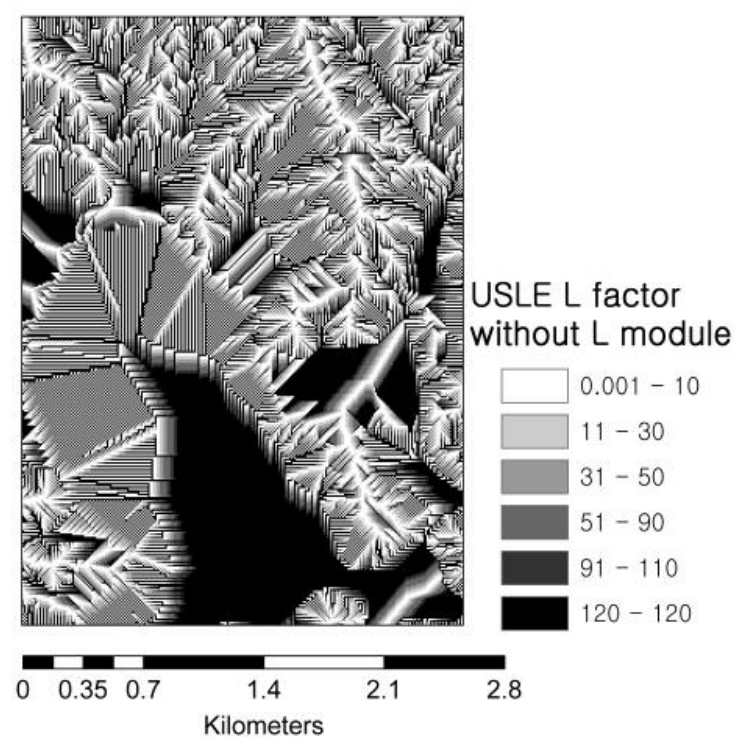

(a) USLE L factor without $\mathrm{L}$ module
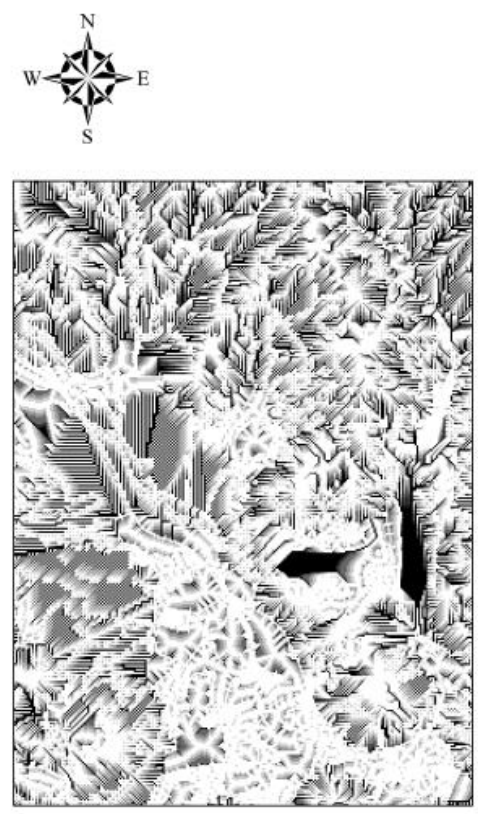

USLE L factor with $L$ module
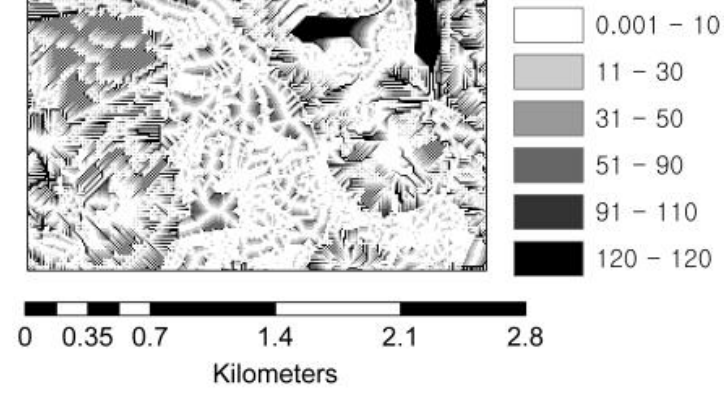

(b) USLE L factor with L module

Fig. 10. Comparison of USLE $L$ factor with $L$ module and without $L$ module.

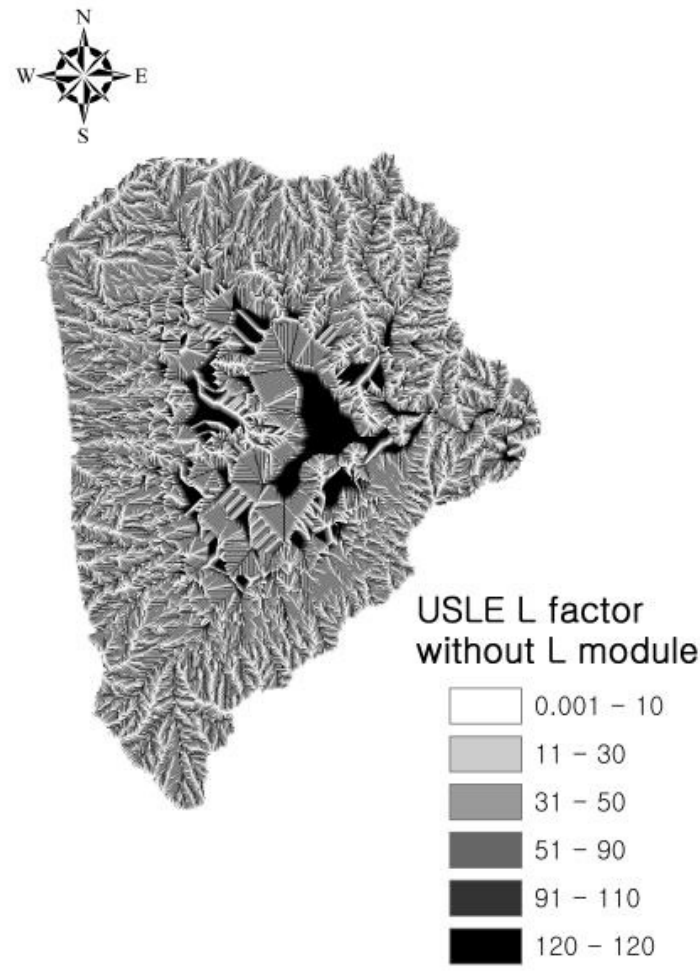

(a) USLE L factor without $\mathrm{L}$ module

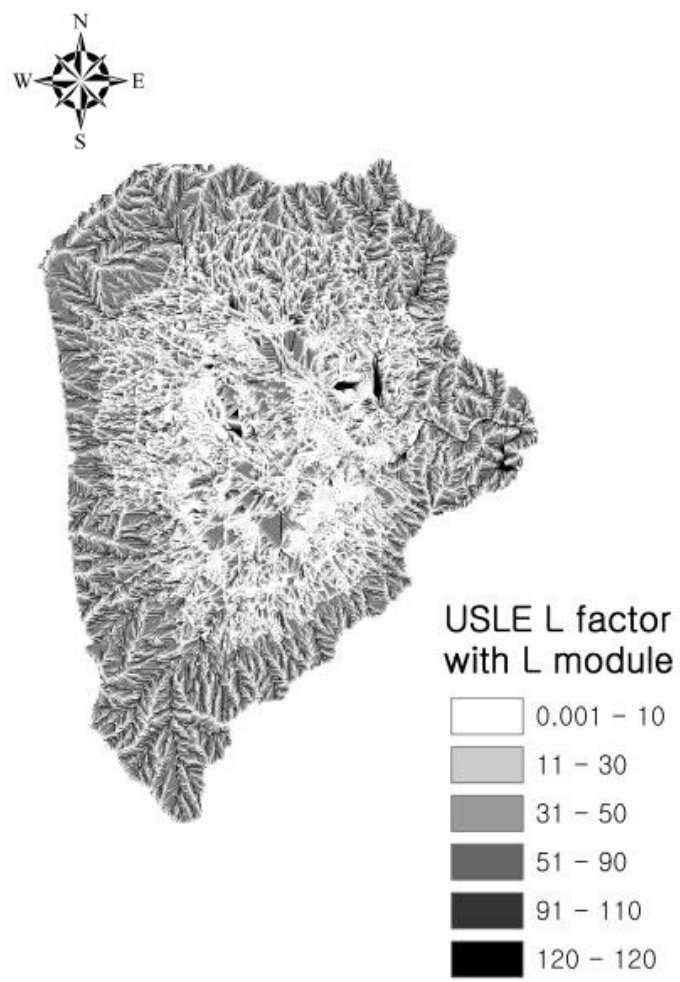

(b) USLE L factor with L module

Fig. 11. Comparison of USLE $L$ factor with $L$ module and without $L$ module. 


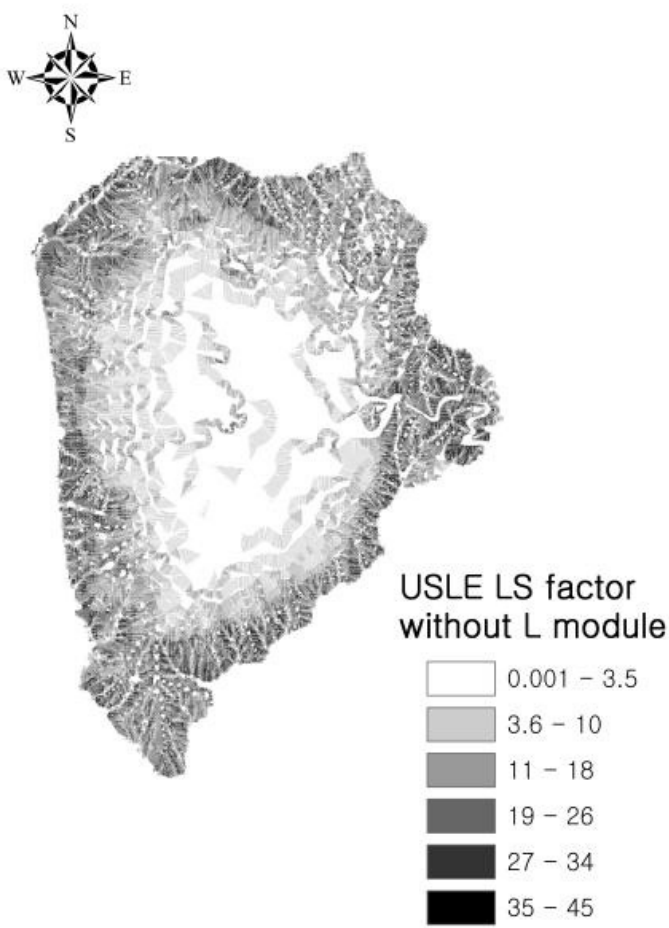

(a) USLE LS factor without L module

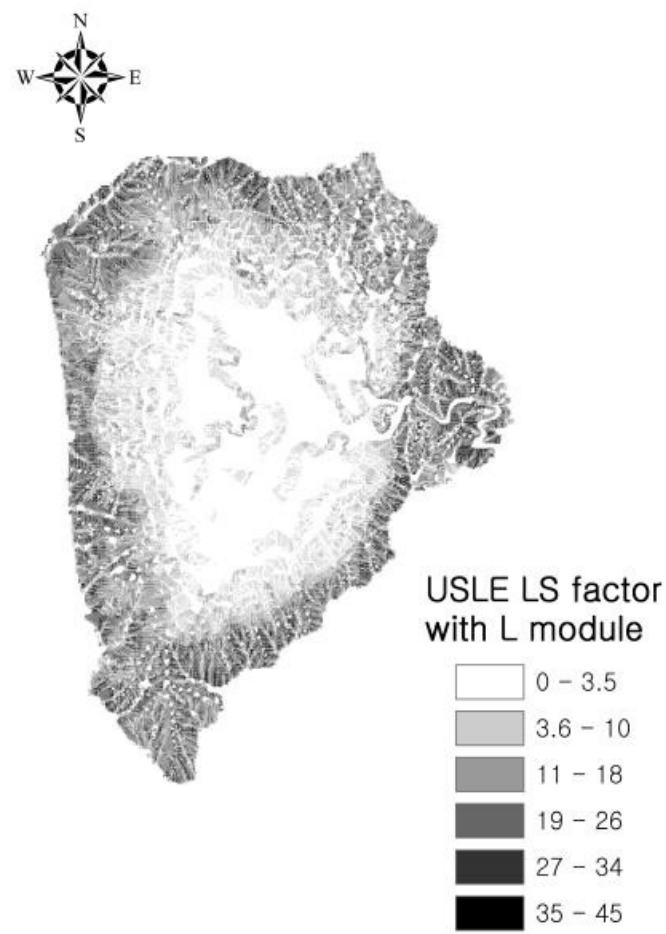

(b) USLE LS factor with L module

Fig. 12. Comparison of USLE LS factor with L module and without L module.

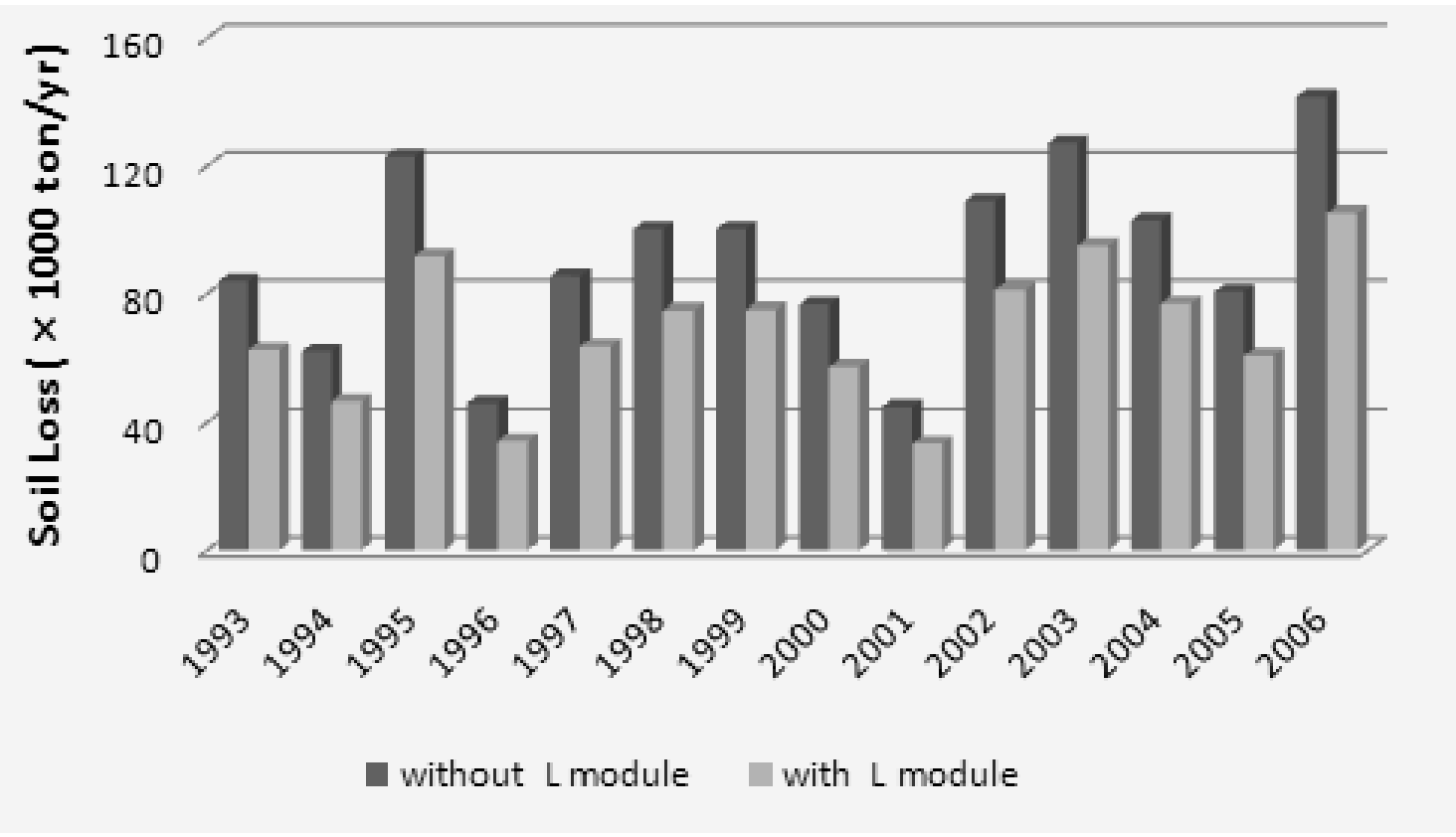

Fig. 13. Comparison of Annual Soil Erosion using SATEEC 2.0. with L Module and without L Module.

by the agricultural field boundaries as shown in Fig. 11 (b). Fig. 12 shows the LS factor estimated without and with SATEEC L module, developed in this study.
The SATEEC L module was applied to the study watershed and total soil erosion values for the study watershed were calculated for 1993 to 2006 (Fig. 13). Annual average soli erosion values were 91,714.71 ton 
and 68,469.49 ton without and with $\mathrm{L}$ module, respectively. The yearly soil erosion result without $\mathrm{L}$ module were greater than that with $\mathrm{L}$ module by $25.34 \%$. These differences are caused by the difference in USLE L factor map as shown in Figs. 11 (a) and (b).

\section{COMPARISON OF SATEEC USING L MODULE WITH SWAT}

The SATEEC system estimates soil erosion and sediment yield using GA-SDR module. In this study, the newly developed SATEEC L module was used to consider field slope length in soil erosion estimation. The GA-SDR module of the SATEEC 2.0 system was used to estimate sediment delivered to the watershed outlet. The SDR, using GA-SDR, with the SATEEC L module was estimated as shown in Equation 9. The coefficient and exponents of SDR equation were 4.36 $\times 10^{-2}, 0.0104,0.1432,0.0090$, respectively. The SDR without the SATEEC L module was also estimated and coefficient and exponents were $1.30 \times 10^{-3}$, 0.0637, 0.6286, 0.2230, respectively (Equation 10).

$$
\begin{aligned}
S D R= & 4.36 \times 10^{-2} \times 61.0742^{0.0104} \\
& \times 257.29^{0.1432} \times 75^{0.0090}=0.1048 \\
S D R= & 1.30 \times 10^{-3} \times 61.0742^{0.0637} \\
& \times 259.78^{0.6286} \times 75^{0.2230}=0.1404
\end{aligned}
$$

For calibration period, the determination coefficient $\left(\mathrm{R}^{2}\right)$ and Nash-Sutcliffe efficiency index $(\mathrm{EI})^{21)}$ with the $\mathrm{L}$ module applied were 0.730 and 0.720

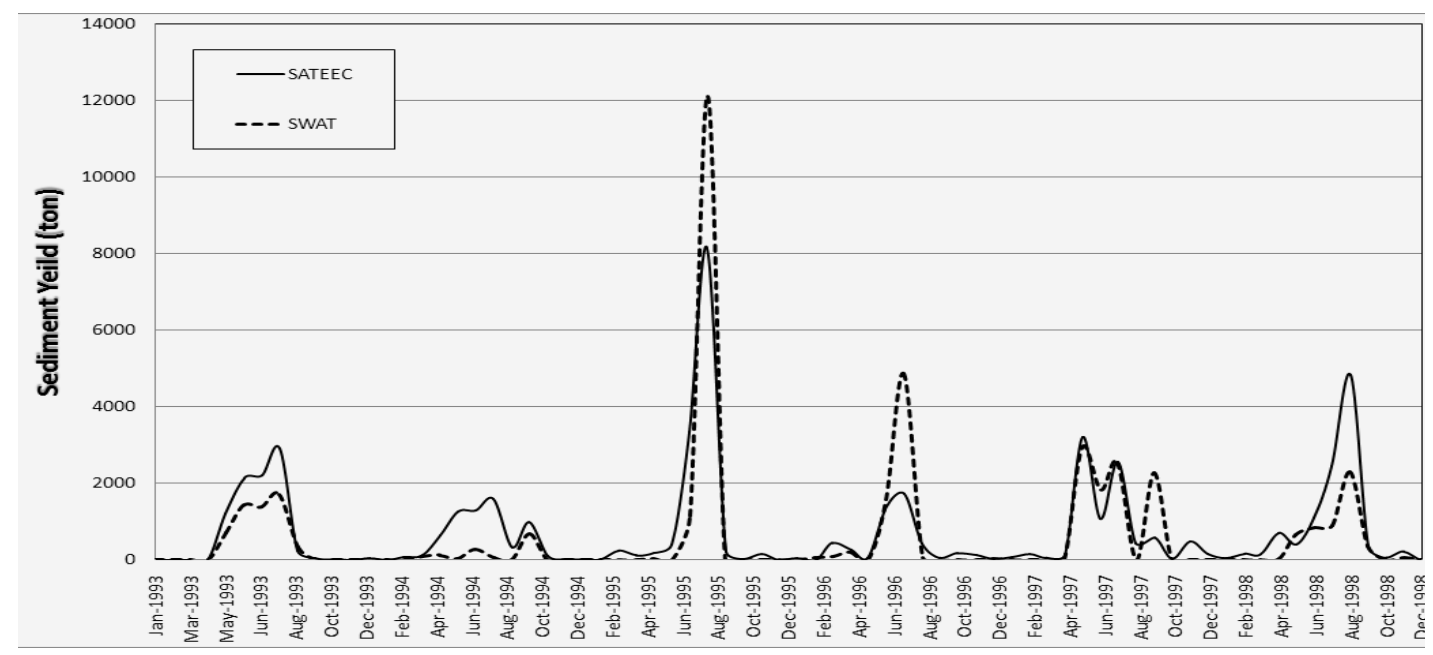

(a) Calibration

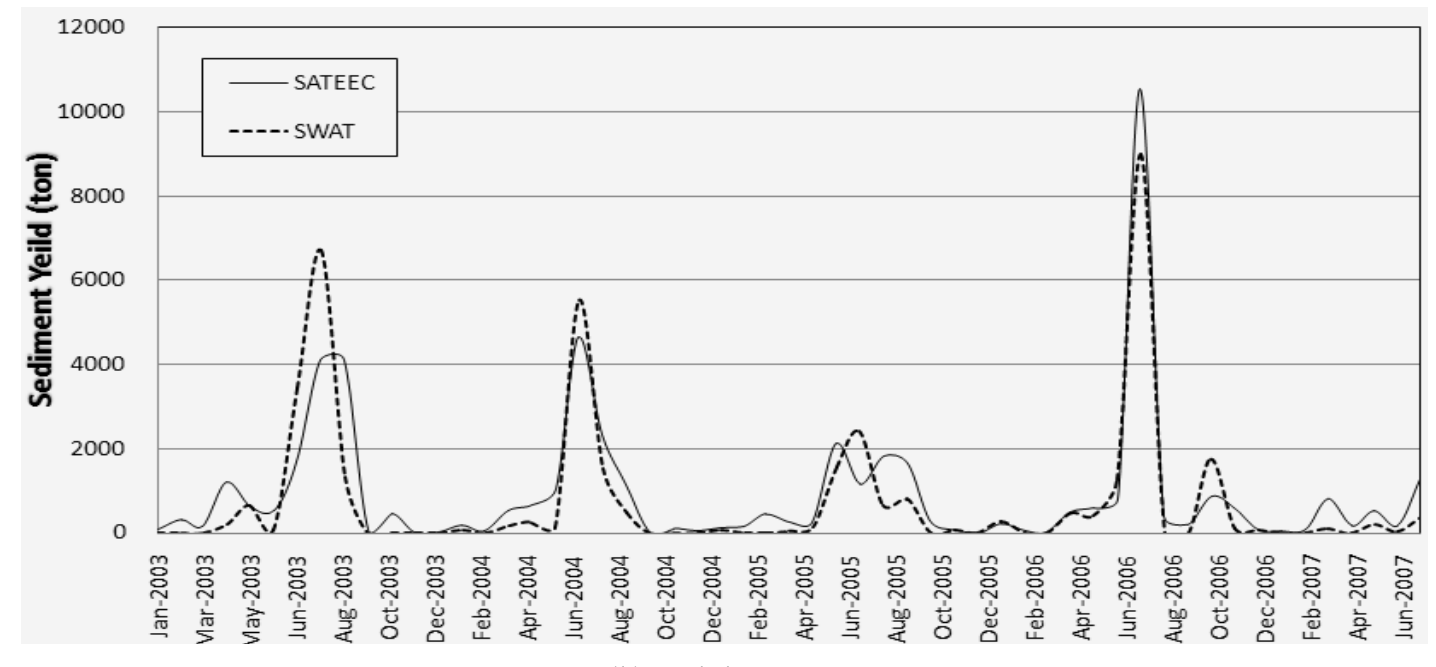

(b) Validation

Fig. 14. Comparison of SATEEC Estimated Sediment using L Module with SWAT Sediment. 


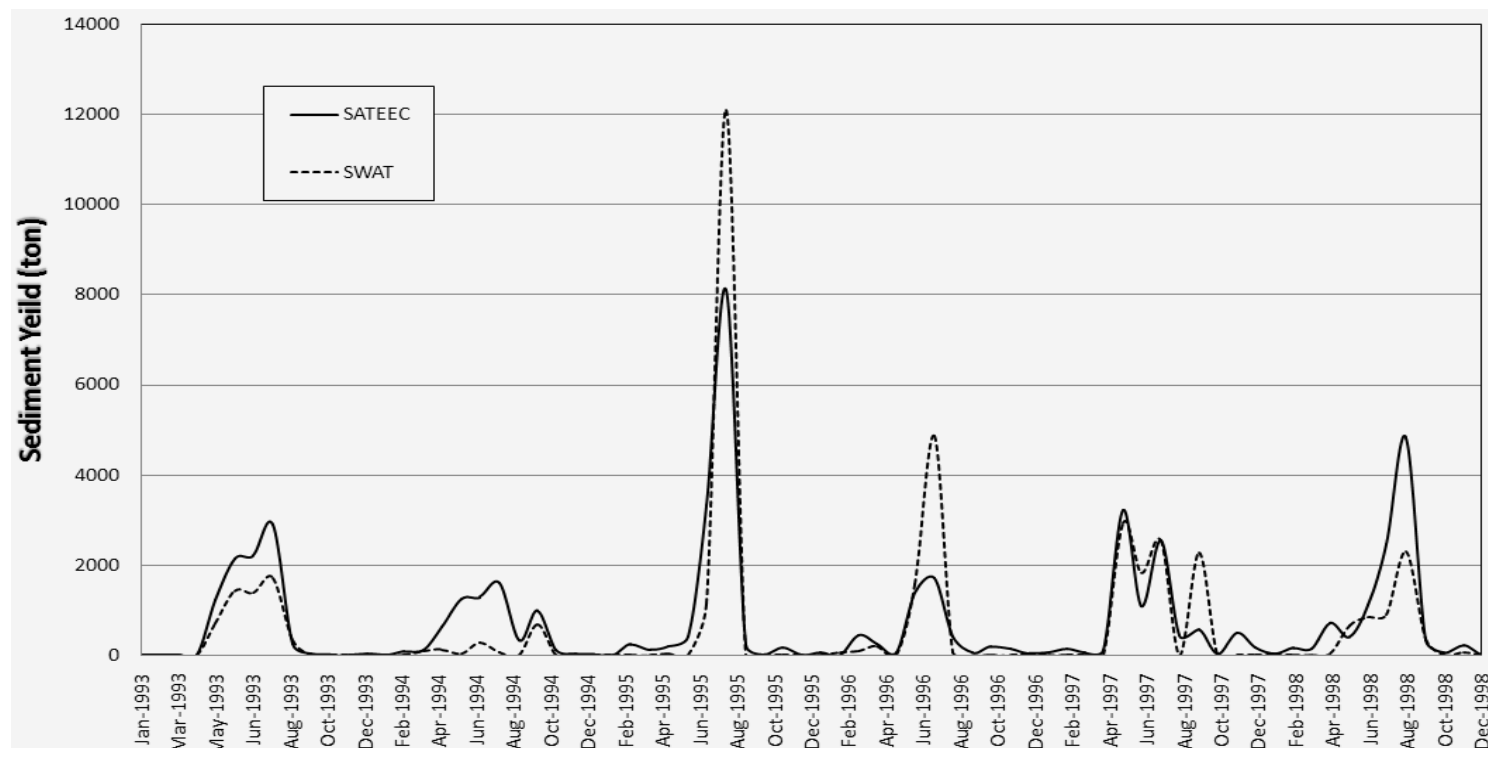

(a) Calibration

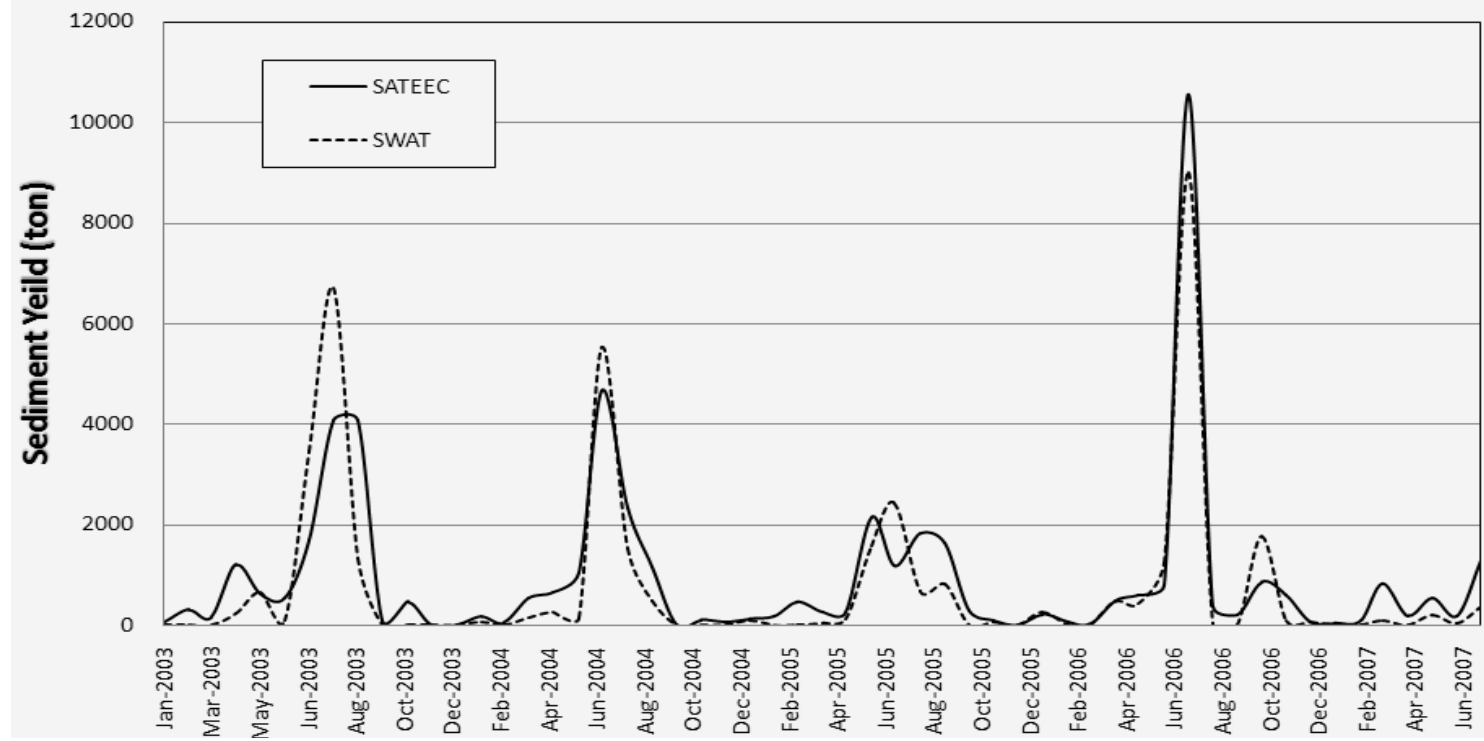

(b) Validation

Fig. 15. Comparison of SATEEC Estimated Sediment using L Module without SWAT Sediment.

respectively Figs. 14 (a) and (b) shows the comparison of the SATEEC estimated values for the validation period. The $R^{2}$ and $E I$ values for the validation period were 0.818 and 0.800 respectively.

For calibration period, the determination coefficient $\left(R^{2}\right)$ and Nash-Sutcliffe efficiency index (EI) without the $\mathrm{L}$ module applied were 0.729 and 0.719 respectively Figs. 15 (a) and (b) shows the comparison of the SATEEC estimated values for the validation period. The $\mathrm{R}^{2}$ and EI values for the validation period were 0.818 and 0.800 respectively.

\section{CONCLUSIONS}

In this study, the SATEEC L module was developed to reflect the slope length segmentations in the fields. The SATEEC L module was applied to the study watershed to analyze the effects of using the SATEEC L module on estimated sediment. As shown in the comparisons between SATEEC estimated sediment with SWAT values, the SATEEC GA-SDR module derives the SDR with reasonably acceptable accuracies. However, it is worthy to note that the soil 
erosion using the SATEEC L module for the study watershed was lower than that without using the SATEEC L module by $25 \%$, although the SATEEC estimated sediment values with and without using $\mathrm{L}$ module match the SWAT sediment values with similar accuracies. This is because the SATEEC GA-SDR module estimates lower SDR in case of greater soil erosion estimation without the L module and greater SDR in case of lower soil erosion estimation with the L module. This indicates that the SATEEC input parameters, especially L factor, need to be prepared with care for accurate estimation of SDR at a watershed scale and for accurate evaluation of BMPs in the watershed.

With the SATEEC L module, developed in this study, various structural and non-structural BMPs can be evaluated properly. The SATEEC 2.0 system with the L module can be used in spatial and temporal studies of soil erosion and sediment transport studies.

\section{ACKNOWLEDGEMENTS}

This study was supported by a grant from Kangwon National University and a grant (code: 2-2-3) from Sustainable Water Resources Research Center of 21st Century Frontier Research Program

\section{References}

1. Brown, L.R., 1984. Conserving soils. In: Brown, L.R. (Ed.), State of the World. Norton, New York, pp. 53-- 75.

2. Wischmeier, W.H. and Smith, D.D. (1978) Predicting rainfall erosion losses. A guide to conservation planning. The USDA Agricultural Handbook No. 537.

3. Flanagan, D.C. and Nearing, M.A. (1995) USDA water erosion prediction project: hillslope profile and watershed model documentation. NSERL Report No. 10. USDA-ARS National Soil Erosion Research Laboratory, West Lafayette, IN 47907-1194.

4. Arnold, J. G., Srinivasan, R., Muttiah, R. S. and Williams, J. R. (1998) Large are hydrologic modeling and assessment part I: model development. Journal of American Water Resources Association 34(1): 73-89.
5. Morgan, R.P.C., Quinton, J.N., Smith, R.E., Govers, G., Poesen, J.W.A., Auerswald, K., Chisci, G., Torri, D. and Styczen, M.E. (1998) The European Soil Erosion Model (EUROSEM): a dynamic approach for predicting sediment transport from fields and small catchments. Earth Surface Processes and Landforms 23, 527-544.

6. Yitayew, M., Pokrzywka, S.J. and Renard, K.G. (1999) Using GIS for facilitating erosion estimation. Applied Engineering in Agriculture 15 (4), 295-301.

7. Ouyang, D. and Bartholic, J. (2001) Web-based GIS application for soil erosion prediction. Proceedings of An International Symposium-Soil Erosion Research for the 21st Century Honolulu, HI. Jan. 3-5.

8. Lufafa, A., Tenywa, M.M., Isabirye, M., Majaliwa, M.J.G. and Woomer, P.L. (2003) Prediction of soil erosion in a Lake Victoria basin catchment using a GIS-based universal soil loss model. Agricultural Systems 76, 883-894.

9. Lim, K. J., Sagong, M., Engel, B. A., Tang, Z., Choi, J. and Kim, K. (2005) GIS-based sediment assessment tool. CATENA 64 (2005) 61-80.

10. Park, Y. S., Kim, J., Kim, N., Kim, S., Jeon, J., Engel, B. A., Jang, W. and Lim, K. J. (2009) Development of New R, C and SDR Modules for the SATEEC GIS System. In revision.

11. Foster, G.R., Renard, K.G., Yoder, D.C., McCool, D.K. and Weesies, G.A., (1996) RUSLE User"s Guide. Soil and Water Cons. Soc.

12. Williams, J. R. (1975) Sediment routing for agricultural watersheds. Water Resour.Bull. 11(5), 965-974.

13. Ouyang, D., and Bartholic J. (1997) Predicting Sediment Devery Ratio in Saginaw Bay Watershed. Proceedings of the 22nd National Association of Environmental Professionals Conference. May 19-23, 1997, Orlando, FL. 659-671.

14. Boyce, R. C. (1975) Sediment Routing with Sediment Delivery Ratios. In: Present and Prospective Technology for ARS, USDA, Washington, D. C.

15. USDA (1972) Sediment Source, Yileds, and Delivery Ratios, National Engineering Handbook, Section 3 Sediment.

16. Vanoni, V. A. (1975) Sedimentation Engineering, Manual and Report No. 54, American Society of 
Civil Engineers, New York, N.Y.

17. Williams, J. R. and Berndt, H. D. (1977) Sediment Yield Prediction Based on Watershed Hydrology, Trans. of the ASAE, 20, pp. 1100-1104.

18. Holland, J.H., 1975. Adaptation in Natural and Artificial Systems. University of Michigan Press, Ann Arbor, MI. 183.

19. Moore, I. and Burch, G. (1986) Physical Basis of the Length-Slope Factor in the Universal Soil Loss
Equation, Soil Science Society of America Journal, 50, pp. 1294-1298.

20. Moore, I. and Burch, G. (1986) Modeling Erosion and Deposition: Topographic Effects, Trans. of the ASAE, 29(6), pp. 1624-1640.

21. Nash, J. E. and Sutcliffe, J. V. (1970) River flow forecasting through conceptual models, Part I - A discussion of principles, J. Hydrol., 10, 282-290. 